\title{
Lima andina. Tras las huellas musicales andinas en Lima (1880-1930)
}

\section{Fred Rohner}

Pontificia Universidad Católica del Perú frohner@pucp.edu.pe

RESUMEN

El siguiente artículo tiene por objetivo discutir cuán andina era Lima antes de los procesos migratorios de mediados del siglo XX, a partir de un conjunto de huellas musicales y sonoras. En ese sentido, busca la existencia de evidencias musicales que revelarian un conjunto de rasgos andinos de la capital peruana antes de la migración moderna. Para ello, busca comprender cuál es el lugar de géneros musicales y performativos, tales como el yaraví y la danza de las pallas, en las construcciones culturales que se han elaborado de Lima como una ciudad escindida de la cultura andina.

Palabras clave: música popular peruana, música andina, música limeña. 


\section{Andean Lima. Searching for the Andean musical traces in Lima (1880-1930)}

\section{ABSTRACT}

On the basis of a set of musical and sound tracks, the following article aims to discuss if Lima was Andean before the migratory processes of the mid-twentieth century. It looks for the existence of musical evidences that would reveal a set of Andean traces in the Peruvian capital before the modern migration. Therefore, it seeks to understand the place of musical and performative genres, such as the yaravi and the danza de las pallas, in the cultural constructions that have been drawing Lima as a city detached from the Andean culture.

Keywords: Peruvian popular music, Andean music, Lima music 
Este artículo tiene su origen en un conjunto de reflexiones elaboradas como parte de lo que fue mi tesis doctoral en la Universidad de Rennes 2 en Bretaña, Francia. No obstante, para ser absolutamente sincero, estas reflexiones se iniciaron hace casi ya diez años, cuando como parte del trabajo de recopilación de las grabaciones del dúo limeño Montes y Manrique logré reunir casi la totalidad de los yaravíes registrados por este dúo para el sello Columbia Records. En esa oportunidad, le llevé las grabaciones a la musicóloga Chalena Vásquez para comentarle el hallazgo, y luego de un natural escepticismo - que en su boca se tradujo como un «no puede ser, compañero»-, nos pusimos a escuchar las grabaciones hasta que el escepticismo inicial se convirtió en un «está chévere». Yo me iniciaba apenas en la investigación musical y el aliento de Chalena, así como su decisión para llevar los yaravíes al programa Presencia Cultural y hacer de conocimiento público este hallazgo, fueron fundamentales para comenzar una búsqueda que no se agotaría solo en los yaravíes del dúo limeño.

Más tarde, luego de haber publicado una breve antología de dichas grabaciones, el trabajo conjunto con Gérard Borras nos llevó a discutir numerosas veces, en público y en privado, cómo la música — en especial estas viejas grabacionesnos permitían repensar algunos de los imaginarios culturales y sonoros dentro de los cuales nos habíamos pensado los peruanos. En 2015, con ocasión de una invitación a participar en el Coloquio de Historia de Lima que la Universidad de San Marcos organizó en homenaje a Miguel Maticorena, tuve la oportunidad de presentar algunas de estas ideas, en particular con respecto a un género musical poco conocido: la lomera, que había sido registrado en los discos Victor de 1928 por los hermanos Áscuez y que había reaparecido en escena tras la grabación a dos viejos músicos originarios de la comunidad de Jicamarca en un trabajo publicado por la Municipalidad de Lima.

Finalmente, dos personas más colaboraron de manera activa en perfilar estas reflexiones. La primera fue el lingüista Rodolfo Cerrón Palomino, quien años 
después de haber sido mi maestro en las aulas, siguió ofreciéndome su cátedra amistosa en conversaciones informales en las que encauzó muchas de mis ideas sobre la andinidad de Lima. La otra persona fue el historiador Jesús Cosamalón, con quien desde hace ya unos años hemos ido colaborando conjuntamente en la consolidación de una historia cultural en el Perú que incorpore todo ese universo de fuentes que la historiografía tradicional ha desdeñado o visto, al menos, con sospecha. Entre esas fuentes y lenguajes, acaso aquel que delineó mejor entre nosotros esa estrecha colaboración haya sido la música. Este artículo, por tanto, debe a todas estas personas los aciertos que en él se hallen y únicamente a mí las malas interpretaciones y los equívocos.

El objetivo de este artículo es, en líneas generales, reflexionar sobre un tema que no ha merecido en los últimos años la atención que requiere: ¿cuán andina era Lima antes de los procesos migratorios de mediados del siglo XX? Desde la aparición de Desborde popular y crisis del Estado del genial Matos Mar - $\mathrm{y}$ antes, incluso, desde los trabajos de Valcárcel y Arguedas - , las ciencias sociales peruanas legitimaron desde la academia un discurso que oponía culturalmente a la capital, Lima, con el resto del país, particularmente el sur andino. Aunque dicho discurso se sostenía sobre un conjunto de evidencias presentes en los presupuestos desde los que actuaba el Estado y desde los que la intelectualidad urbana imaginaba el país, lo cierto es que pocas veces el esfuerzo de los científicos sociales peruanos del siglo XX ahondó en las manifestaciones culturales propias de los sectores populares limeños más allá de un conjunto de fenómenos concebidos $a$ priori como «cultura popular limeña».

Siempre me ha resultado curiosa la asociación, por ejemplo, que se ha elaborado de algunos distritos y zonas de la capital con una cultura particular y, hay que decirlo, con una población específica. El Rímac, por ejemplo, ha sido sindicado como un barrio básicamente poblado por afrodescendientes ${ }^{1}$; no obstante, el censo de 1908 señalaba un conjunto de datos que, al menos, debería hacernos pensar en otras direcciones: mestizos, $38 \%$, blancos, $36 \%$, indios $17 \%$ y negros $5 \%$ (Panfichi, 1998, p. 36). Más allá del crecimiento del número de mestizos —en el que sin duda se camuflaban diversas poblaciones -, lo interesante es que, pese a ello, el número de sujetos que eran percibidos como «indios» por el censor era bastante mayor que el de «negros». Algo similar se aprecia en otros espacios de la ciudad, como Barrios Altos.

1 Quizá quien mejor colaboró con esta compartimentización de la ciudad fue Alberto Flores Galindo en su célebre Buscando a un inca (2005). 
¿Por qué, entonces, se ha invisibilizado durante tanto tiempo la significativa presencia de una población indígena local capitalina? Algunos han aducido que se trata de una población que, culturalmente, se hallaba ya acriollada, y que por lo tanto podría contarse mejor entre el grupo de mestizos que en el de indios en sentido estricto. Sin embargo, no es posible suponer que, como en el caso de otras poblaciones, estos «indios» hubiesen mantenido un conjunto de fenómenos culturales propios, distintos de los de otros grupos culturales de la ciudad, del mismo modo que se ha señalado en el caso de los afrodescendientes. ¿No es posible suponer también que, como en el caso de los afrodescendientes, esas manifestaciones que se sindicaban como exclusivas de esa población no lo hayan sido del todo y que la convivencia en los mismos barrios y la interacción en los distintos espacios de sociabilidad que la ciudad ofrecía haya hecho de estas manifestaciones una suerte de patrimonio común entre una buena parte de los limeños, pese a que podían ser percibidas de manera heterogénea?

En última instancia, la pregunta que queremos responder es si no es posible imaginar una Lima andina en el período republicano antes de las migraciones de mediados del siglo XX. La interrogante es, como se aprecia, bastante amplia; por ello, en este trabajo queremos detenernos únicamente en un conjunto de trazas en el ámbito musical que, a nuestro parecer, nos ofrecen algunas claves para repensar el asunto de las identidades culturales en la Lima de fines del siglo XIX e inicios del siglo XX. La finalidad de estas reflexiones es poner a la luz un conjunto de evidencias que nos permitan superar — al menos en la academia — las escisiones desde las que hemos construido y pensado las identidades en el Perú.

Desde una perspectiva más bien metodológica, centraremos nuestra atención en las grabaciones realizadas por las disqueras norteamericanas entre 1911 y 1930 a diferentes intérpretes peruanos, y sobre todo limeños, como en el caso del dúo Montes y Manrique o el conjunto de los hermanos Áscuez. Estas grabaciones representan, en la actualidad, una de las fuentes más interesantes para aproximarse al fenómeno sonoro limeño de las primeras décadas del siglo XX. Asimismo, la lectura conjunta de estas fuentes con pasajes de la literatura costumbrista de la época nos permitirá bosquejar con mayor nitidez algunos rasgos del universo musical limeño del período de entresiglos. En ese sentido, trabajaremos aquí sobre un conjunto de ejemplos musicales incluidos en esas grabaciones que representaron, para nosotros mismos, las primeras llamadas de atención sobre la aparente falta de concordancia entre el imaginario sonoro limeño de esos años y la irrupción de un conjunto de piezas o fragmentos musicales que parecerían apuntar en otras direcciones. 


\title{
EL CARNAVAL DE MONTES Y MANRIQUE
}

Lo interesante de las grabaciones que realizaran Montes y Manrique para la Columbia Records en 1911 ha sido siempre el hallarse en un lugar liminal entre la cultura popular tradicional del XIX y la nueva cultura popular que desde fines de ese siglo comenzaba a transformarse de manera sustancial en las formas y modos de producción musical. Por ello, no es extraño encontrarnos dentro del repertorio de estos cantores con muestras cuyo sentido social parece estar asociado aún con formas rítmicas, musicales y culturales, en general, del siglo XIX. No obstante, lo valioso de este repertorio es que allí mismo encontramos también las primeras muestras de esa transformación.

En la tercera serie de discos peruanos producidos por la Columbia Records se incluyó el diálogo cómico titulado «Un carnaval» (P42). No obstante, contrariamente a lo que podría esperarse en esta pieza, no se muestran - o no de manera evidente - referencias al son de los diablos (la expresión musical más característicamente asociada con esta fiesta) ni en los diálogos que conforman esta pieza dramática, ni en los ritmos y géneros musicales incluidos ${ }^{2}$. Sin embargo, otras referencias musicales hacen de este diálogo cómico un caso bastante singular en la representación del paisaje sonoro limeño ${ }^{3}$.

La pieza es generosa en su ambientación de la fiesta del carnaval, pues revela de manera condensada las distintas etapas e instancias de la fiesta, desde los espacios públicos hasta los privados. Esta dramatización se inicia con un conjunto de pregones de vendedores de huevos, chisguetes y polvos de colores especiales «para los chinos». Tras una intentona por mojar a un chino, la comparsa de muchachos se dirige hacia la casa de una señorita (Rebequita) cantando algo similar — rítmica, armónica y melódicamente - a los cacharparis grabados por las mismas disqueras en esos años:

\author{
Desde la otra banda vengo \\ por venirte a ver \\ a ver si me quieres \\ ingrata mujer \\ por eso mi vida \\ te vengo a mojar \\ y que $[\ldots]$ vida \\ el ño Carnaval.
}

\footnotetext{
2 Sobre la presencia de diablos y sones de diablos en el carnaval limeño es útil el trabajo de Rojas (2005).

3 Sobre la noción de paisaje sonoro siguen siendo útiles las ideas de Murray Shaffer (1977).
} 
Al llegar a la puerta de la señorita, los jóvenes cantan una especie de serenata (en danza habanera) como anuncio de su llegada; una vez dentro de la casa, comienza el juego de carnaval con sus «cataratas de aguas», y para finalizar la pieza se canta el vals «Rebeca», luego de lo cual se hace el anuncio de que, al día siguiente, para finalizar el carnaval, todos se dirigirán a La Punta.

Es interesante que muchas de las escenas que podemos apreciar en esta breve pieza cómica han sido descritas de manera similar — sobre la base de las crónicas periodísticas - por Rolando Rojas en su estudio sobre el carnaval para las primeras décadas del siglo XX. En el estudio de Rojas, sin embargo, la presencia musical parece circunscribirse al son de los diablos o a los bailes privados. Del mismo modo, un artículo de José Gálvez (firmado con el seudónimo de Proama), publicado en Variedades, es bastante rico en esas referencias (Gálvez, 1912). Allí se encuentran reelaboradas por la nostalgia del periodista las cuadrillas de jóvenes que acuden a los bailes y a los juegos en casas particulares; allí también el entierro en el mar de la Punta de Ño Carnavalón. Sin embargo, el artículo es obsequioso al describir el carnaval en el Callao en la representación de otros elementos y de otros leitmotivs del carnaval tradicional:

En La Punta se ha jugado bastante, y el miércoles de ceniza se ha enterrado con solemnidad y pompa al carnaval de 1912, y las fiestas han estado concurridísimas como todos los años. Allí resucitan una vez cada 365 días el palo ensebado, las mágicas ollas, los circos baratos, entre el resonar platillesco de las desaforadas bandas de cachimbos.

Además de la referencia a juegos como «el palo ensebado» o «las ollas», el artículo refiere a otra forma musical que lamentablemente es difícil caracterizar y definir: los cachimbos ${ }^{4}$. Ya antes, en un pasaje de la Gaceta de Gobierno de 1775, nos habíamos topado con el mismo nombre para una danza que acompañaba la procesión del Corpus. En este caso, la referencia mantiene la idea de que se trata de una especie de cuadrilla o de banda, pero la única alusión a un elemento sonoro se encuentra en la expresión «resonar platillesco». No obstante, esta referencia nos permite suponer que la música callejera de esas festividades excedía la presencia única de diablos.

4 El diccionario de Salvá de 1846 define al «cachimbo» como un «negro arrogante». Es interesante, sin embargo, que ya en el diccionario de Toro y Gómez de 1901 el significado de esta voz sea: «músico de una orquesta militar o de aficionados». Consultado en Real Academia de la Lengua Española. Nuevo Tesoro Lexicográfico: http://ntlle.rae.es/ntlle/SrvltGUIMenu Ntlle?cmd $=$ Lema\&sec $=1.0 .0 .0 .0$. 
Las fotografías que acompañan al artículo, por lo demás, revelan la presencia de otros elementos vinculados con un universo musical particular como la presencia de un «árbol carnavalesco» en el Callao, que no es otra cosa que un árbol de yunza. Esto nos permite, al menos, conjeturar la presencia de otras formas musicales, como aquellas que acompañan el talado de la yunza en otras regiones aledañas a Lima (Tompkins, 2011, pp. 170-174). Asimismo, otra fotografía en este artículo presenta a una comparsa de enmascarados «trompetilleros». Aunque la fotografía no es totalmente nítida, puede distinguirse al menos una media docena de cornetas o pequeñas chirimías que nos devuelven sobre otras sonoridades adicionales como parte de la fiesta de carnaval (Gálvez, 1912, pp. 225-233).

Por ello, la pieza de Montes y Manrique es reveladora en varios sentidos: en primer lugar, nos muestra un pincelazo de lo que aquellos que han estudiado el carnaval de inicios del siglo XX han referido en sus trabajos (Rojas, 2005; Muñoz, 2001), y en segundo lugar, nos ayuda también a reconstruir — bajo la forma de una representación, claro está- el paisaje sonoro de las calles de la ciudad durante dicha celebración. Sin duda muchos otros elementos del paisaje sonoro quedarán excluidos de la pieza, como los señalados por Proama en Variedades; no obstante, la representación distingue un conjunto de sonoridades particularmente interesantes, como la serenata o el cacharpari ${ }^{5}$.

Sin duda, tiene un valor especial el cacharpari cantado por la comparsa que adereza la fiesta del carnaval, pues, contraviniendo el imaginario cultural de lo limeño y lo criollo, nos revela cómo algunas danzas asociadas más bien al universo sonoro de los Andes peruanos pudieron formar parte del repertorio musical de dichas celebraciones en la ciudad de Lima, aun cuando este caso pueda parecer raro o excepcional. Lo interesante de esta pieza es que su línea melódica parece una mixtura de carnavales de otras latitudes, especialmente similar en su introducción al carnaval arequipeño ${ }^{6}$.

Si bien es posible que muchas de las otras piezas reunidas para estas grabaciones - tal como sugieren Luis Salazar (2014), José Antonio Lloréns y Rodrigo Chocano (2009, pp. 107-110) — hayan intentado representar a otros espacios

5 Se ha elegido la denominación de cacharpari a falta de una especificación del género en la propia pieza dramática. Asimismo, se ha preferido este apelativo debido a que, dentro de la serie de discos P de la Columbia — entre los que se encuentran las grabaciones de Montes y Manrique-, existe un tema grabado por una banda con ese mismo nombre dentro del cual una de las secciones es asimilable rítmicamente a lo cantado por el dúo en la pieza dedicada al carnaval.

6 Un ejemplo de lo dicho puede encontrarse entre el minuto 1.14 y 1.32 en el siguiente video: https://www.youtube.com/watch?v=cfq3wGGQFpg 
regionales del Perú, ¿hasta qué punto podemos filiar esta pieza dentro de ese caudal de repertorio aprendido ad hoc para los registros discográficos? Toda la pieza, como señalamos antes, intenta recrear el ambiente del carnaval limeño, desde los ataques a los chinos hasta la promesa de ir a matar el carnaval en el balneario de La Punta ${ }^{7}$. En ese sentido, nos parece más sensato presumir que, dentro de ese contexto, la pieza del carnaval incluida dentro del diálogo intenta también reflejar parte de esa sonoridad del carnaval que se escuchaba en la Lima de inicios del siglo XX y esa sonoridad era, si se quiere, «andina». Este no será — como veremos más adelante — el único ejemplo que haga referencia a elementos andinos como parte del paisaje sonoro y performativo de la ciudad.

Por ello, aunque en la mayor parte de construcciones culturales de fines del XIX e inicios del XX se presente a Lima como una ciudad criolla, lo cierto es que la población limeña era bastante más heterogénea de lo que suele dibujarse. Asimismo, es importante recalcar que la noción de criollo desde la cual se han configurado las prácticas culturales limeñas y su propia identidad no es necesariamente la misma que sirvió para esos propósitos durante el siglo XIX, y quizás aun en las primeras décadas del siglo XX.

Lima, en tanto capital, por lo demás, recibía de antiguo a poblaciones de diversos lugares del país, ya sea de manera temporal (viajeros, arrieros, etc., que hacían estación brevemente en la ciudad) o de manera más permanente. Son bastante conocidas las representaciones de la «pallas de Corongo» de Pancho Fierro, que venían a Lima con motivo de las fiestas religiosas. Sin embargo, las pallas aparecían ya representadas en el relato del Corpus de 1775 como parte de la procesión. Asimismo, Palma, en su tradición denominada «El mes de diciembre en la antigua Lima», relatando la misa de Aguinaldo, expresará lo siguiente:

Una orquesta criolla, con cantores y cantoras de la hebra, hacía oír todos los airecitos populares en boga [...] Lo religioso y sagrado no excluía a lo mundanal y profano. Al final de la misa, un grupo de pallas bailaba la cachua y el maisillo, cantando coplas no siempre muy ortodoxas. [...] La Nochebuena, con su misa de Gallo, era el no hay más allá del criollismo [...] A las doce solo el populacho quedaba en la plaza multiplicando las libaciones.

\footnotetext{
Al respecto pueden leerse las descripciones del entierro del Ño Carnavalón o de Momo en el balneario de La Punta en el Callao que registrara año tras año la revista Variedades. Consúltese, por ejemplo, el artículo de Gálvez (1912, pp. 225-233). Sobre este aspecto es también interesante el testimonio de Áscuez (1983, p. 15). Dice Áscuez lo siguiente: «Los miércoles de ceniza en La Punta se hacía una fiesta con un carnavalón muy grande. [...] El carnavalón era un muñeco gigante vestido de colores y que se arrojaba al mar por la noche».
} 
La aristocracia y la clase media se encaminaban a los templos donde las pallas cantaban en el atrio villancicos [...] (1953, p. 1198).

La presencia de las pallas en la época de Navidad debió ser bastante tradicional - o, al menos, así lo señala el tradicionalista-. Lo interesante es que epítetos como «criollo» parecen no confrontarse con la referencia a las pallas. Ellas, sus coplas y sus villancicos forman parte de ese universo cultural sin problematización alguna en el relato de Palma. No será Palma el único cronista que dedique algunas líneas a estos personajes y a su resonancia en la musicalidad callejera de la ciudad; también Carlos Prince, a finales del siglo XIX, dedicó algunas líneas a estas pallas:

Las Pascuas y el año nuevo, salían las payas [sic] a recorrer la población. Eran las payas [sic] unas indias jóvenes, vestidas a la usanza de su pueblo, que iban acompañadas de sus respectivas parejas y de una diminuta orquesta, compuesta de harpa, violín y pitos de caña que ellos fabrican. Las payas [sic] bailan en las calles y entran a las casas a hacer lo mismo

El relato de Prince, pese a ser bastante breve y no entrar en muchos detalles, nos muestra sin embargo algunos elementos que vale la pena destacar. Se trata, como puede inferirse, de un conjunto de jóvenes «indias» - lo que no resultaba tan evidente en el relato de Palma - provenientes de regiones aledañas a la ciudad que, no obstante, hacen estación en la capital obedeciendo a cierto ciclo en el calendario, pues, según afirma el autor, estas indias circulaban por la ciudad cada año por espacio de una semana, la que va entre las pascuas de Navidad y el año nuevo. Además de bailar en las calles, nos dice Prince que estas muchachas entraban a las casas a ejecutar sus bailes, por lo que es posible presumir que existiese ya familiaridad de la población urbana con estas formas musicales.

$8 \quad$ Prince (2011 [1890], p. 31). No sabemos con exactitud qué música era la interpretada por estas «indias jóvenes» y sus orquestas en estas fiestas (aun cuando Palma identifique al menos tres géneros: cachuas, maisillos y villancicos), pero es posible presumir — por las fechas de las celebraciones, navidad y año nuevo, y quizás también por la instrumentación, arpa y violín (la inclusión de las flautas podría indicar algo distinto, sin embargo) - que se tratase de un género similar a las huaylillas que se interpretan en varias regiones de los Andes peruanos con ocasión de las fiestas de fin de año. Sobre esta idea han sido especialmente ricas las conversaciones con Luis Salazar. Al respecto es interesante la nota propuesta por Juan de Arona (1938, p. 255). Sobre la voz «jualijía» (derivada de la entrada «hualijía»), dirá Arona lo siguiente: «Danzas de navidad que las negras de las haciendas de Cañete bailaban delante de los nacimientos, golpeando el suelo y marcando la cadencia con una especie de árbol artificial adornado de oropeles y papelitos de colores». 
No debían resultar extrañas las melodías que estos músicos ejecutaban al oído del limeño para que Prince haya incluido a estos personajes entre sus «tipos limeños de antaño». Sin duda, este tipo de crónicas (así como las del carnaval) nos muestran separaciones; existen bailes de «indios» y bailes de «negros», pero dichas separaciones ceden espacio a una suerte de convivencia pública de manifestaciones culturales y musicales que terminarán por constituir el patrimonio y el imaginario sonoro de la ciudad. Un sujeto puede sentir ajeno a su constructo social o étnico alguno de estos bailes, pero los ha visto, han penetrado sus melodías en él, su cuerpo ha reaccionado y ha vibrado de gusto o repulsa; lo que no puede afirmarse es que no los conociera, pues ya estas danzas, estas músicas, organizaban parte del calendario vital de la ciudad ${ }^{9}$.

Por ello, volviendo a la pieza del carnaval, es especialmente valioso el que todas estas piezas (pregones, cacharpari, habanera y vals) aparezcan retratadas como parte de distintos momentos de la celebración. La inclusión del vals «Rebeca», además, nos revela cómo este género iba ganando cada vez más espacios dentro de las celebraciones de los sectores populares y convivía con otros géneros, como la habanera, o aun con géneros más tradicionales en el Perú.

Aunque la música de las calles limeñas que configuraron el paisaje sonoro de la capital peruana - en el que el vals vendrá luego a insertarse - incluye bastante más que pregones, danzas de diablos, cacharparis y pallas, nos parece pertinente detenernos un momento para analizar las motivaciones que han terminado por configurar el universo musical limeño como un constructo cerrado en el que estos dos últimos ejemplos (cacharpari y danza de pallas) no parecen tener cabida sino solo como excepciones o como errores de interpretación.

¿Hasta qué punto es excepcional este tipo de manifestaciones musicales? ¿Cuánto del acervo musical andino formaba parte del paisaje sonoro de una ciudad como Lima, tan fuertemente caracterizada como una ciudad criolla? Más interesante aún, ¿cuánto de esta sonoridad no se trasladó al vals en su proceso de adaptación en la ciudad de Lima? Aunque la oposición procedente de las categorías «andino»

Sobre la permanencia de la danza de las pallas y su apropiación dentro del universo sonoro limeño, es interesante la versión del dirigente obrero Julio Portocarrero recogida por Lloréns y Chocano (2009, p. 72). En la relación sobre una fiesta popular en un callejón a inicios del siglo XX, Portocarrero afirmará lo siguiente: «En esas ocasiones había, por ejemplo, las payas [sic], que era gente de la misma vecindad: muchachas, jovencitas, adolescentes que se vestían... procuraban vestirse como payas [sic], como se acostumbraba en aquella época, con sus cintas, varas llenas de cascabeles y bailaba y cantaban esas cosas ellas».

Encontramos un testimonio similar para el mismo barrio de Malambo en uno de los artículos de Augusto Áscuez (1982, p. 15). 
y «criollo» ha formado parte de los imaginarios desde los que se han construido las identidades regionales en el Perú, vale la pena revisar estas categorías y responder, en última instancia, cuán andinos eran musicalmente los limeños a fines del siglo XIX e inicios del siglo XX y cuánto de esas caracterizaciones no ha obedecido al sustrato ideológico de los formuladores principales de esa división más que al retrato mismo de ese paisaje sonoro y cultural.

En 1888, tras el oprobio de la guerra y la ocupación chilena de las principales ciudades del Perú, Manuel González Prada sancionó en su polémico Discurso en el Politeama un anatema que habría de proporcionar las claves en las que las generaciones posteriores habrían de pensar las identidades locales y nacionales:

No forman el verdadero Perú las agrupaciones de criollos i estranjeros que habitan la faja de tierra situada entre el Pacífico i los Andes; la nación está formada por las muchedumbres de indios diseminadas en la banda oriental de la cordillera. Trescientos años há que el indio rastrea en las capas inferiores de la civilización, siendo un híbrido con los vicios del bárbaro i sin las virtudes del europeo: enseñadle siquiera a leer i escribir, i veréis si en un cuarto de siglo se levanta o no a la dignidad de hombre ${ }^{10}$.

Este pasaje, sobre el que ha vuelto buena parte de los científicos sociales peruanos, fue por mucho tiempo uno de los hitos principales del sistema educativo peruano y zanjó, para muchos, todo tipo de discusión sobre las identidades étnicas y su asociación con un espacio geográfico.

Esta línea de pensamiento, por lo demás, puede rastrearse en las primeras décadas del siglo XX entre polos opuestos del pensamiento en el Perú. Las ideas de González Prada alimentaron por igual a Riva Agüero que a Mariátegui, quienes desde orillas distintas dialogaron con el viejo maestro de formas también diversas. No en vano nos recuerda Flores Galindo la aparente contradicción que significaba que un joven de la élite más rancia en el Perú (Riva Agüero) asumiera un viaje por el sur andino del país cuando su clase le reclamaba otro comportamiento, otro itinerario (Flores Galindo, 1987). Así, es a partir de estas ideas de González Prada (las que pueden hallarse bosquejadas ya en la célebre Carta a los peruanos de Flora Tristán ${ }^{11}$ ) que comenzarán a construirse proyectos políticos no pragmáticos,

10 González Prada, Manuel. «Discurso en el Politeama» en Pájinas libres. Consultado en http:// www.biblioteca.org.ar/libros/211590.pdf

11 Este extenso fragmento puede dar una idea bastante clara de la consonancia entre las ideas de Tristán y el discurso de González Prada:

[...] Cuando la totalidad de los individuos sepa leer y escribir, cuando los periódicos penetren hasta la choza del indio, entonces, encontrando en el pueblo jueces, cuya censura habréis de 
como los del Partido Socialista y el Apra, e incluso los de ese social cristianismo heterodoxo que representó Víctor Andrés Belaunde. Aun en las intervenciones parlamentarias plagadas de elitismo y de un discurso que bordea el racismo más flagrante, Belaunde proponía en el debate constitucional pensar al indio como un otro al que hay que procurar un conjunto de medios emancipadores en la clave propuesta por González Prada (Belaunde, 1933). Aun más, los críticos de dicha posibilidad (Alejandro Deustua o Clemente Palma), para quienes la incapacidad del indio debía obedecer a cuestiones de su naturaleza, cifraban sus ideas en diálogo franco y abierto con las del Discurso en el Politeama.

Por ello, no resulta extraño que en el discurso indigenista - y, más tarde, en las construcciones de unas ciencias sociales - se repitieran sin mayor problema algunas de las inexactitudes más graves del discurso de González Prada. Este discurso, aprendido en nuestras ciencias sociales por la vía de Mariátegui, había sistematizado al Perú también de manera dicotómica en cuanto a la construcción de identidades tanto sociales y culturales como étnicas; la aceptación de ese discurso dio como resultado que no se profundizara, en muchas ocasiones, en los vacíos que sospechosamente debían asaltar al que confrontara el corpus ideológico del ensayista con las otras muchas informaciones, noticias y datos registrales de la época.

Uno de esos puntos clave del discurso se encuentra en la localización de los sujetos que formarán parte de dicha dicotomía: criollos-costa / indios-sierra. Esta reducción, dispensable si se piensa en el discurso político incendiado de González Prada, pasó a convertirse en una verdad incuestionable de nuestras ciencias sociales. Es interesante, por ello, que sean estudiantes del mismo Flores Galindo (de cuyas ideas, inspiradas en la lectura mariateguista de González Prada se habían nutrido las ciencias sociales peruanas del último tercio del siglo XX), sobre todo historiadores, los que comenzaran a mirar con mayor sospecha dichas afirmaciones y quienes, desde un conjunto de estudios casuísticos, cuestionaron las simplificaciones de ese discurso: Juan Carlos Estenssoro, en sus estudios de la música colonial ${ }^{12}$; Cecilia Méndez y su revisión crítica de la construcción

temer y cuyos sufragios debéis buscar, adquiriréis las virtudes que os faltan. [...] Instruid, pues, al pueblo; es por allí donde debéis empezar para entrar a la vía de la prosperidad (Tristán, 2003, pp. 71-72).

12 Uno de los trabajos emblemáticos de este autor es Música y sociedad coloniales. Lima 16801830. Otro trabajo de singular importancia es «La plebe ilustrada. El pueblo en las fronteras de la razón» (1996). 
de categorías culturales en el siglo XIX ${ }^{13}$; Carlos Aguirre, en su revisión de la asociación entre bandolerismo y etnicidad ${ }^{14}$, y junto con ellos, otros historiadores que no alcanzaron a Flores Galindo en las aulas como Jesús Cosamalón ${ }^{15}$, entre otros, quienes siguieron algunos de los cabos sueltos dejados por la lectura que Flores Galindo había hecho de este discurso y propusieron releer la historia incluyendo aquellas fuentes y datos con los que otros muchos investigadores se toparon sin detenerse realmente en ellos ${ }^{16}$.

Es sintomático, por ejemplo (y ya en el ámbito musical, que es el que realmente nos compete), que cuando José Antonio Lloréns publica en la década de $1980 \mathrm{su}$ Música popular en Lima: criollos y andinos, esta división se haya mantenido de manera categórica; el propio libro estaba organizado de esa manera. Es cierto que el objeto de estudio de Lloréns en esa oportunidad no comprendía precisamente la música de fines del siglo XIX e inicios del XX, sino que su atención estaba más bien puesta en las décadas posteriores; aun así, a este investigador debemos algunas de las divisiones y categorizaciones más importantes sobre la música limeña, y por ello sorprende el que dichas divisiones formen parte de la estructura fundamental de su estudio. Por ejemplo, el que se haya asumido que lo criollo costeño era algo absolutamente diferenciado de lo andino, como si fuesen dos categorías que por naturaleza se excluían mutuamente ${ }^{17}$.

Lo cierto es que el ejemplo de Lloréns no es sino uno más de aquellos que se desprenden de la lectura apresurada de las ideas de González Prada. La oposición criollo / andino había creado un binomio difícil de superar a lo largo del siglo $\mathrm{XX}$. No obstante, las propias fuentes nos fueron sugiriendo que dicha dicotomía

13 Aunque uno de los trabajos pioneros de esta autora en ese sentido fue Incas sí, indios no. Apuntes para el estudio del nacionalismo criollo en el Perú (2000), el artículo que mejor revela la lectura que señalamos es «De indio a serrano. Nociones de raza y geografía en el Perú (siglos XVIII-XXI)» (2011, pp. 53-102).

14 El trabajo que mejor ilustra el desarrollo de las ideas de Flores Galindo por este autor es Agentes de su propia libertad: los esclavos de Lima y la desintegración de la esclavitud, 1821-1854 (1993).

15 El primer trabajo de Cosamalón que cuestionó algunas de las interpretaciones de Flores Galindo fue Indios detrás de la muralla. Matrimonios indígenas y convivencia racial en Santa Ana (Lima 1795-1820) (1999). En el año 2017, sin embargo, Cosamalón publicó el trabajo más completo que conocemos sobre la problemática racial en la Lima de los primeros años de la república: El juego de las apariencias.

16 Rolando Rojas (2014) ha destacado también el rol de algunos de estos historiadores en la renovación de los estudios históricos en el Perú.

17 Algunos ecos de esta separación vistos desde el mundo andino pueden encontrarse en los testimonios estudiados por Zoila Mendoza (2006). 
debía mirarse más cuidadosamente y que, quizás, era necesario repensar categorías absolutas como las de «criollo», «andino», «serrano», etc., que se desprendían de esta lectura. Lo primero que había que preguntarse del discurso de González Prada es hasta qué punto puede afirmarse que el Perú estuviese dividido entre criollos en la costa e indios en la sierra. Cualquiera que haya pasado revista a censos, libros parroquiales, etc., habrá podido constatar que, aunque pudiese existir una mayor proporcionalidad de ciertos grupos poblacionales en ciertas regiones, esta mayor proporcionalidad no representaba a la totalidad de la población, pero sobre todo, esta mirada desatendía los roles que dichas poblaciones distintas cumplían al interior de sus comunidades y a la manera como estos sujetos construían sus identidades ${ }^{18}$.

En ese sentido, es interesante la cita que de un pasaje de la Lima del 900 de Eudocio Carrera ofrece Alicia del Águila en su texto sobre espacios públicos y redes sociales en la Lima de inicios del siglo XX. La autora analiza el espacio del exterior de la iglesia del Baratillo (en el Rímac) en cuanto a las formas de encuentro menos rígidas que se daban fuera de la iglesia, y cita el siguiente pasaje: «Caldeaban un tanto el ambiente esos cholos coronguinos de a pie y a burro, hoy desaparecidos, con sus pregones, español cabeceado con serrano» $(1997)^{19}$. La cita es más extensa, pero lo que nos interesa resaltar es cómo esta socióloga interpreta esta primera parte del pasaje citado, pues ello revela hasta qué punto la posibilidad de encuentros entre poblaciones más heterogéneas ha sido invisibilizado por un sustrato ideológico incapaz de conciliar la coexistencia - difícil muchas veces, otras violenta, pero algunas veces también fluida - entre gentes de procedencia étnica distinta. Al analizar la cita, Del Águila dirá lo siguiente «Tanto los negros coronguinos como Nicanor de la Maza constituían personajes irreverentes $[\ldots]$... Más allá de la irreverencia o no de los personajes, lo interesante es cómo esta investigadora termina por transformar a los «cholos coronguinos» en «negros coronguinos».

Persigamos la ideología detrás de esta cita: para la autora, la localización de la iglesia del Baratillo (distrito del Rímac, cerca del antiguo arrabal de San Lázaro,

$18 \mathrm{Al}$ respecto siguen siendo estimulantes, pese al tiempo transcurrido, las ideas de Fernando Fuenzalida sobre los modos en que los sujetos van modelando sus identidades y van cambiando, con el pasar del tiempo y debido a su relocalización social, su filiación étnica. Al respecto léase Fuenzalida (2009, pp. 141-204).

19 Sobre el origen y las acepciones de «cholo» puede consultarse el siguiente trabajo de Luis Andrade: «Un argumento a favor del origen mochica de CHOLO». En Actas del II Congreso Internacional de Lexicología y Lexicografía en homenaje a Diego de Villegas y Quevedo Saavedra (pp. 71-97). Academia Peruana de la Lengua. 
barrio encomendado a leprosos y más tarde señalado como habitación de negros esclavos, durante la colonia) hace impensable que los «coronguinos» pudieran ser algo distinto que afrodescendientes. Desde que Flores Galindo recordó a los científicos sociales peruanos que la estructura fundacional de la ciudad de Lima había previsto un cercado de indios y un barrio para los esclavos, se ha repetido como un sonsonete esta sentencia de una ciudad ghetizada $(2005, \text { p. } 241)^{20}$. Solo algunos investigadores cuya lucidez crítica no se contentó con explicaciones apriorísticas pudieron penetrar en la permeabilidad de las estructuras físicas de la ciudad colonial (más tarde republicana) y confrontarnos con una realidad bastante menos rígida (en apariencia) que permitía la confluencia de distintos grupos en ciertos espacios, lo que, sin duda, generaba intercambios culturales y ese complejo acrisolamiento que ha solido denominarse mestizaje. Esto no acababa con el ghetto, pero el ghetto no era ya necesariamente una realidad de la physis urbana: era más bien una condición social, un orden legal y una coartada para encauzar los múltiples desbordes populares que se generaban en la convivencia cotidiana, como bien ha apuntado Cosamalón (1999, p. 70).

Aunque Cosamalón centra su estudio a fines del siglo XVIII e inicios del XIX - es decir, en el ocaso de la vida colonial - , lo cierto es que, a través de su estudio de la parroquia de Santa Ana (en lo que pasaría a llamarse los Barrios Altos), nos revela una ciudad en la que el contacto entre las distintas poblaciones que integran lo que Flores Galindo denominó «la plebe» no era inusual. En primer lugar, Cosamalón nos alerta sobre la necesidad de incluir a «los indios» dentro de esa plebe de la que Flores Galindo los había excluido por intentar localizarlos, bien en el espacio cerrado del Cercado, o bien en los caseríos aislados de pescadores, donde - a decir del autor - mantuvieron una duradera libertad. Cosamalón, como había hecho ya Estenssoro domiciliando a los músicos coloniales, integra a los «indios» al paisaje y a las dinámicas de la ciudad. Algunos son forasteros ya instalados en Lima, otros parecen ser oriundos del valle, pero todos alternan en pulperías, chinganas y trabajos ocasionales con el resto de castas que conformaban los grupos subalternos de la ciudad (1999, pp. 200-212).

El retrato del paisaje sonoro limeño de fines del siglo XIX no puede escamotear ideológicamente las construcciones musicales de todos estos grupos. La desaparición de referencias raciales y étnicas de los censos - como han apuntado Arrelucea y Cosamalón en otro trabajo - no significa la desaparición

20 Este capítulo no apareció publicado en las primeras dos ediciones del libro y no vio la luz sino hasta 1988. 
de estas poblaciones ni de sus prácticas culturales y musicales (2015, pp. 60; 118-119). Por ello debemos presumir que el universo musical limeño de fines del siglo XIX debe representarse dentro de coordenadas sonoras múltiples que incluyen, sin duda, las formas de representación musical pública de poblaciones de origen afro, indígena y mestizo.

Aunque Santa Cruz y Tompkins han identificado el canto de décimas y marineras como prácticas propias de los grupos de afrodescendientes limeños, lo cierto es que los sectores populares eran, como hemos señalado, bastante más heterogéneos en su conformación social y étnica. La presencia pública de una población indígena limeña es una realidad sobre la que algunos historiadores han llamado la atención cada vez con más ahínco y de manera mejor documentada; asimismo, la existencia de una población migrante y de tránsito a lo largo del siglo XIX proveniente otras regiones del país (y del continente) tampoco puede evadirse.

Ya en el siglo XX, algunas otras fuentes darán cuenta de esta convivencia multiétnica en la ciudad de Lima. Así lo declara Hugo Marquina en un volumen compilado por Enrique Paz Soldán con el título de Lima y sus suburbios cuando, al describir la calle de Malambo en «Cincuenta casas de vecindad en la avenida Francisco Pizarro», afirma que:

Malambo era una sucesión de callejones, tiendas, solares habitados casi exclusivamente por negros y mulatos. Había uno que otro tambo, astrosos y típicos con cuartos de alojamiento para las personas y corrales para los animales. El más conocido de estos tambos era el de Huamantanga que permitía que la nota morena general se matizara de amarillo bronceado, color de los cholos arrieros de Santa Rosa de Quives, de Canta y de Huarochirí; cholos arrieros en los cuales la devoción al señor de Huamantanga, a las cruces rurales, a las yunzas y a las pallas constituían las más fuertes pasiones de su vida (Paz Soldán, 1957, p. 78).

Aun cuando Marquina afirma la preminencia de la población afrodescendiente en este sector de la ciudad - tal como lo afirmasen también Flores Galindo y Alicia del Águila - a este autor no se le escapa la presencia regular, aunque no se trate de su lugar de vivienda, de una población andina que hacía estación en la ciudad en su calidad de arrieros. Su estadía en esos tambos era, sin duda, motivo suficiente para que ambas poblaciones interactuaran, aun cuando su trato no haya sido necesariamente armonioso. Lo cierto es que el propio texto de Marquina los revela como individuos que hacen una vida pública más allá de su trabajo como arrieros. El autor los muestra involucrados en festividades como las de las pallas, las cruces o las yunzas, todas ellas actividades públicas. 
El espacio público funciona por ello como una suerte de laboratorio acústico en el que distintas formas musicales y no musicales alternan y generan, en el mejor de los casos, un tipo de conocimiento sonoro particular o, al menos, crea las condiciones materiales necesarias para familiarizar a la población con universos sonoros diversos. La creencia en una experiencia sonora limitada solo por las características culturales y estéticas de un grupo al interior de la ciudad parece no condecirse con la multiplicidad de estímulos sonoros organizados con los que estos interactúan y con los espacios de sociabilidad en los que las personas se interrelacionaban. Sin embargo, no solo en las actividades y fiestas públicas es posible hallar algunas huellas de esa diversidad sonora: también existieron otras formas musicales de origen andino asociadas más bien a una forma de actividad musical quizás bastante más privada. Este es el caso del yaraví.

\section{EL YARAVÍ: LOS SONIDOS ANDINOS DE LIMA}

No es posible determinar de manera muy precisa si, como parte de las tradiciones de la población indígena limeña o de algunos de esos grupos migrantes o de tránsito, otro género musical había de ocupar un lugar determinante en el universo musical limeño: el yaraví. La ubicación de este género al interior del universo musical limeño representó, desde que iniciamos el trabajo con los materiales musicales de inicios del siglo XX, uno de los cuestionamientos más fuertes a aquello que habitualmente se había considerado parte de las tradiciones musicales criollas limeñas.

Todos los que habían estudiado el yaraví hasta entonces (Varallanos, Carpio Muñoz y, en menor medida, Pagaza) habían considerado al yaraví como un género de raigambre andina y, por lo tanto, se le suponía lejano - por no decir ajenoa espacios como Lima, caracterizada como una ciudad criolla (con todo lo que aquello pudiera significar ${ }^{21}$. Los primeros ejemplos musicales que nos alertaron en este sentido los debemos a la revisión de la obra de Montes y Manrique. Desde que nos propusimos editar la obra de estos dos cantores para el aniversario de dichas grabaciones (2011), una de las primeras tareas que abordamos fue la recolección de todas las piezas registradas por el dúo limeño para la Columbia Records en Nueva York. Dicha tarea nos confrontó con una aparente contradicción: en el imaginario de los músicos limeños (pese a no haber escuchado hasta entonces

21 Una nutrida reseña de las ideas de algunos de estos folcloristas puede hallarse en Romero (2012, pp. 289-329). 
suficientes grabaciones del dúo, o quizás por ello mismo) se suponía a Montes y Manrique como «los padres del criollismo». Así lo sancionaba un vals del compositor chalaco Manuel Raygada:

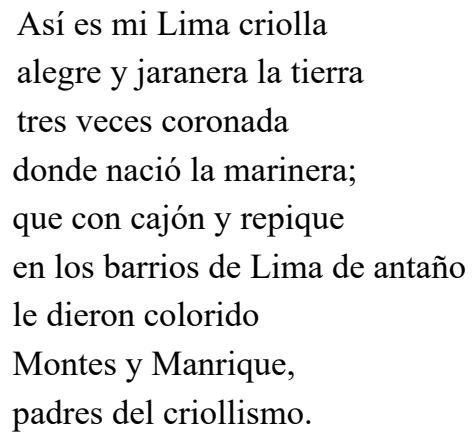

Esto, en buena cuenta, significaba la asociación de los cantores con un conjunto de ritmos y de géneros musicales propios de lo que desde mediados del siglo XX se había considerado «criollo». Criollos eran los valses, criollas las polcas y las marineras, criollos los tonderos, pero algunos de los géneros grabados por el dúo parecían no calzar del todo con ese imaginario. Para pocos era criolla la danza-canción o habanera (que contaba con más de veinte registros entre las grabaciones del dúo); lo mismo podría decirse de los tristes. El límite era extraño: el triste, en tanto género, se pensaba siempre como una introducción al tondero, y por ello, desde mediados del siglo XX solían cantarse bajo esa estructura solo algunos versos que podían ir de una a dos cuartetas. El contraste, por ello, entre los tristes grabados a mediados del siglo XX con los registrados por Montes y Manrique en 1911 era significativo: en el caso del dúo limeño, los tristes eran canciones completas y autónomas que comprendían, en su mayoría, más de tres estrofas de manera regular.,

Junto con los tristes —o para ser exactos, más que cualquiera otro de los géneros grabados por Montes y Manrique-, lo que destacaba entre su repertorio eran los yaravíes, y de ello dejamos constancia en varias oportunidades (Rohner, 2007; Rohner y Borras, 2010). El yaraví fue el género que contó con mayor número de grabaciones entre los registros del dúo para la serie de discos peruanos de la Columbia. Sobre ello es bastante lo que se ha especulado. Tanto Lloréns como Salazar atribuyen dichas grabaciones al hecho de que el repertorio que estaba siendo registrado por estos cantores debía tener un alcance nacional, pues era así como se presentaban dichas grabaciones: «los discos de música 
nacional del Perú». La idea es sugerente y no deja de tener asidero; sin embargo, tampoco nos satisface del todo. A diferencia de Lloréns, para quien la grabación de yaravíes responde solo a una estrategia comercial de la disquera y de las casas comerciales (la Casa Holtig, en primer lugar, que fue la que corrió con los gastos del viaje y que por ello tuvo la exclusividad para la venta de los discos durante los primeros años que siguieron a las grabaciones), lo cierto es que el hecho de que Montes y Manrique hayan grabado más de cuarenta yaravíes nos permite sospechar que el género no les era del todo extraño y no parecía ser solo parte de un repertorio ajeno estudiado para la grabación discográfica. Así lo ha propuesto Lloréns, y algo similar plantea Luis Salazar cuando afirma que dichas canciones corresponden a un listado de yaravíes recopilados por Daniel Alomía Robles ${ }^{22}$. Salazar es bastante más meticuloso en su investigación y su propuesta señala que Montes y Manrique aprendieron dichos yaravíes de Alomía Robles, puesto que la mayor parte de los yaravíes cantados por el dúo limeño corresponden a las recopilaciones de Robles. La idea es bastante sugerente; sin embargo, el propio Salazar reconoce que entre las grabaciones de Montes y Manrique y las recopilaciones del folclorista huanuqueño existen numerosas variantes, lo que ya puede inclinarnos a pensar en otras direcciones.

Sin descartar del todo la idea de que parte del repertorio de Montes y Manrique (en cuanto a los yaravíes) haya sido aprendida para las grabaciones, creemos que es posible suponer que muchos de esos yaravíes no eran patrimonio solo de algunas regiones peruanas (como ha querido afirmarse hasta el cansancio: triste - región norte peruana y yaraví - Arequipa y sierra sur peruana), sino que se trataba de canciones panandinas que eran también conocidas y cantadas por los músicos limeños ${ }^{23}$. Esto, que parece bastante natural (Lima, pese a quien le pese, sigue siendo parte del territorio andino a pesar de su centralismo y su capitalidad), ha sido causa de los más airados debates y de la asunción de posturas categóricas en contra de esa posible «andinidad» de Lima a inicios del siglo XX. Sin duda, el sustrato detrás de esas afirmaciones y de esas posturas proviene de

22 Salazar ha afirmado esta idea en diversas oportunidades. E1 23 de febrero de 2014, por ejemplo, en un ciclo de conferencias organizado por Rafael Santa Cruz en el Centro Cultural de España (Lima), Salazar volvió sobre esa misma idea (CCE, 23 de febrero de 2014).

23 Otros testimonios apoyan esta idea; entre los yaravíes grabados por Montes y Manrique encontramos uno titulado El pajarillo cuyo texto y línea melódica se conocen también en el norte de la Argentina y en el Ecuador. Aunque los testimonios argentinos y ecuatorianos son más tardíos (el primero de la segunda mitad del siglo XX y el segundo de la década de 1940), las variantes propias de esos textos nos permiten suponer que no se trata de canciones que tuvieran como fuente directa la versión de 1911. 
la dicotomía fundada por González Prada. Herederos, la mayor parte de nuestros científicos sociales, de las ideas de González Prada por el filtro de Mariátegui $-\mathrm{y}$, en cuanto a los estudios antropológicos y folclóricos, por el filtro más duro aun de Arguedas - , suponer que el yaraví pudiese ser también un género limeño resultaba aberrante ${ }^{24}$. El yaraví era andino y no podía ser criollo, pues lo criollo había pasado a representar exclusión, racismo y centralismo ${ }^{25}$.

No le faltaba razón a Arguedas en su momento, pues a decir verdad ya desde fines del siglo XIX venía construyéndose una limeñidad criolla separada de manifestaciones panandinas que podían haberla hermanado, en otro tiempo, a otras muchas ciudades del país como Ayacucho, Tarma o Cusco. No obstante, estas separaciones - aun a inicios del siglo XX — parecían mostrar intersticios y vasos comunicantes entre manifestaciones culturales que solo unos pocos años después se creería miraban hacia horizontes absolutamente opuestos e irreconciliables.

En esa clave se fueron construyendo las identidades locales y nacionales. El poder político comenzó a constituirse de aquella manera desde estos centros culturales escindidos, y limeños y costeños se pensaron a sí mismos en esta nueva clave. Algunos cabos sueltos quedaban, sin embargo, y ellos no se mostraban necesariamente en las dimensiones políticas y sociales, pero la cultura representaba una dimensión más difícil y más lenta de hacer confluir en esa dirección. Por ello, los yaravíes de Montes y Manrique despertaban tantas animadversiones, pero a la vez nos revelaban uno de esos ámbitos en los que la volubilidad de las manifestaciones culturales permitía aún mostrar capas, más y menos, soterradas de manifestaciones más heterodoxas y más plurales. Se podía ser limeño y guardar aun elementos de manifestaciones panandinas ${ }^{26}$.

Para muchos, esa posible «andinidad» debía estar cifrada en el triste, pero no en el yaraví. Esta última postura era, a nuestro criterio, la más frágil. Si bien es cierto - como ha demostrado Luis Salazar - que en las grabaciones de Montes y Manrique, frente a la extrema similitud entre tristes y yaravíes, la diferencia se encuentra en las introducciones que realiza la guitarra en uno y otro género ${ }^{27}$, también lo es que esta regularidad tiene al menos dos excepciones en el propio

24 El texto de Arguedas que mejor ilustra dicha ideología para los estudios musicales es Indios, mestizos y señores (1989).

25 Esta asociación también puede hallarse en las indagaciones literarias sobre el yaraví de Cornejo Polar (1989).

26 Sobre este tema fueron especialmente valiosas las conversaciones con Rodolfo Cerrón Palomino.

27 Según Salazar, las introducciones de los yaravíes obedecen a la secuencia tónica-subdominantedominante y la de los tristes solo a la secuencia tónica-dominante. 
repertorio de Montes y Manrique. Más aún, dicha regularidad no se mantiene si a los ejemplos proporcionados por el dúo limeño sumamos al análisis los otros muchos ejemplos de estos géneros que editó la Victor TM en los años 1913, 1917, 1928 y 1930 por intérpretes muy diversos. En muchos de esos ejemplos, la secuencia de las introducciones varía de manera menos predecible. Como reconoce el mismo Salazar, la secuencia de las introducciones de los yaravíes de Montes y Manrique, conocida como la introducción básica del yaraví arequipeño, no es utilizada mayoritariamente por los dúos arequipeños que entonces (1913 y 1917) registran canciones dentro de este género. A esto hay que añadir que canciones que en una oportunidad son grabadas como yaravíes son grabadas en otro momento (o por otros músicos en los mismos años) como tristes.

Esto no debería resultar extraño. Juan de Arona, en su clásico Diccionario de peruanismos, decía que «triste» era la voz con que en la costa se conocía al yaraví (1938, p. 377). Y la presencia del yaraví, además, puede rastrearse en Lima hasta el siglo XVIII, como nos recuerda Arróspide de la Flor siguiendo un dato ofrecido por Guillermo Lohmann al referirse a los músicos virreinales que pudieron colaborar con la música de un conjunto de obras lírico-dramáticas de Pedro de Peralta:

Frente a esta vertiente del arte cortesano en la vida musical del Virreynato, fluye el aporte vernacular. Sabido es que indios, negros, mulatos y criollos, mostraron calidades especialmente deseables para la música y el baile, desde sus primeros contactos con el arte occidental. Esta aptitud se hizo mayormente manifiesta, igual que en el área de las artes plásticas, conforme se fue afirmando una fisonomía propia en nuestra cultura. Son múltiples, en esta época, las referencias a artistas nativos de singulares méritos, así como a piezas, como la Canción Changuitollay y múltiples yaravíes (Arróspide, 1971, p. 46).

Antes que ellos, Pagaza ya había ofrecido suficientes datos para bosquejar un mapa continental de la presencia del yaraví desde fines del mismo siglo (1960, pp. 75-90). El yaraví, además, como veremos más adelante, había logrado insertarse en el siglo XIX dentro de espacios donde este tipo de manifestaciones musicales se encontraban, aparentemente, menos enraizadas.

En ese sentido es bastante significativo el encontrarnos con ejemplos de algunos yaravíes (Gotas de llanto, Imposibles, El corazón, etc.), que al menos fueron interpretados en dos oportunidades distintas en las veladas literarias de Juana Manuela Gorriti (1892). Por lo demás, el comentario de estas interpretaciones suele ser bastante elogioso, como se deja ver en los comentarios de la prensa 
incluidos dentro de la edición de las Veladas. Así, por ejemplo, el 3 de agosto de 1876 El Nacional dirá lo siguiente: «El señor Escobedo volvió a ocupar el piano y ejecutó un delicado yaraví titulado Gotas de llanto». Es interesante que en este caso el articulista se refiera al yaraví con el epíteto «delicado», puesto que este tipo de adjetivos solía estar reservado para la música europea y rara vez aludía a la música nativa.

Asimismo, debía gozar el yaraví de cierto prestigio entre estos grupos, pues en otra de las veladas la señora Carolina García de Bambarén recita un poema suyo titulado «El yaraví peruano» en el que dice lo siguiente:

Vino tampoco de Albión

Ni de la ligera Francia

Ni de España, en gusto rancia

Tan bella y dulce canción:

$\mathrm{Y}$, aunque recorriera así

África, Asia y Oceanía

Música igual no hallaría

Al peruano yaraví (Gorriti,1892, p. 406).

El elogio que realiza esta autora del yaraví peruano está relacionado, sin duda, con ese protoindigenismo que comenzaba a gestarse a fines del siglo XIX. No obstante, lo más interesante es que, aun cuando pueda tratarse solo de una estrategia poética, Carolina García identifique al yaraví como una forma musical peruana, es decir, nacional. Dicha identificación — puesto que yaravíes pueden hallarse desde la Argentina hasta el Ecuador - hace de este género, como en el caso de la zamacueca, un símbolo de lo nacional. Aunque es difícil constatar cuántas de estas ideas eran compartidas por el resto de la élite ilustrada, lo cierto es que elogios y defensas como estas eran ya antiguas. Recordemos que a fines del siglo XVIII se desató una polémica en el Mercurio Peruano entre Sicramio y Del Campo sobre las «potencialidades musicales» del yaraví (Estenssoro, 1989, pp. 33-37). Esto, lejos de ser un dato curioso, constituye una de las pruebas más contundentes sobre la presencia de este género entre la población limeña. Aun cuando se caracterice como una forma musical propia de los indios, Del Campo afirma haber oído estos yaravíes en un «perfecto drama músico», lo que secunda la información ofrecida por Arróspide de la Flor.

Por ello, no debe extrañarnos que, asentada la república, nos hallemos con manifestaciones de aprecio hacia este género como la vertida por Carolina García; 
por esos mismos años podemos encontrar yaravíes también entre las recopilaciones arregladas para piano por Claudio Rebagliati y otros muchos ejemplos más en las partituras de fines de ese siglo que consumían las élites letradas del momento de compositores más diversos como Romualdo Alva, Ventura Morales o Calixto Pacheco, aunque Pacheco se encuentre ciertamente más próximo a las corriente protoindigenistas musicales (ver Rebagliati, s/f). Asimismo, vale la pena destacar que, ya en los primeros años del siglo XX, nos hallamos con yaravíes cuya música se debe a compositores afrodescendientes, como en el caso del yaraví La flor del cariño, compuesto por Justo Arredondo con letra de Abelardo Gamarra.

Aun cuando durante el siglo XIX este género estuviese asociado a la población indígena, el yaraví, por lo que puede apreciarse, no era pues un género estrictamente «andino» (en el sentido que hoy tiene la palabra); debido a su propagación en otros grupos de la población limeña, el yaraví era también una manifestación cultural mestiza y uno de los ejemplos más claros de lo que a fines del XIX podía ser caracterizado como música criolla. La música criolla o mestiza no estaba integrada aún por valses y polcas, sino que comprendía otros géneros, como los que describirían Palma o Fuentes aludiendo a las músicas nacionales o de la tierra. Criollas, en ese sentido, eran las zamacuecas, pero también criollos podían ser los yaravíes o los huaynos ${ }^{28}$. El problema, creemos, viene de una concepción bastante cerrada (y muchas veces anacrónica) del término que lo volvía sinónimo de costeño, y para muchos, simplemente de limeño. En tanto significante de formas de mestizaje cultural, lo criollo como categoría - en esos años- debe ser entendido como un continuum bastante flexible en el que distintas manifestaciones de orígenes también diversos se asociaban con otras manifestaciones o con elementos (pensemos en instrumentaciones, estructuras retóricas, etc.) propios de otras tradiciones que en un espacio tan diverso (y con lugares públicos de confluencia multicultural) terminaban por acrisolarse en distintas direcciones hasta ganar estabilidad ontológica y canonizar ciertas formas y estructuras ${ }^{29}$.

Pero así como el yaraví puede ser entendido como criollo, también hay que agregar que esto no le restaba esa aparente «andinidad» evidente en los intervalos

28 Aunque volveremos sobre este pasaje en otras oportunidades, vale la pena destacar que en la nota celebratoria de la revista Música peruana de Alejandro Ayarza, publicada el 7 de diciembre de 1912 (p. 1147) el articulista colocará al huaynito como una de esas «viejas cosas de sabor puramente criollo».

29 Para una revisión histórica del término consúltese el artículo de Luis Gómez (2007). También es útil la ampliación de la discusión en la tesis del mismo autor (2010). 
y en su estructura melódica y armónica. Lo mismo, bien analizado, podría decirse de otras muchas manifestaciones musicales pensadas como netamente criollas o limeñas, o incluso entre muchas manifestaciones musicales caracterizadas tardíamente como afroperuanas ${ }^{30}$. Lo cierto es que el criollo, el limeño en sus manifestaciones culturales es —o era — también andino (incluso en el sentido más cerrado que se da hoy al término). Esta «andinidad» del limeño, sin embargo, se ha querido minimizar a lo largo del siglo XX como un mecanismo de empoderamiento de los migrantes provenientes de la sierra sur del Perú de mediados de siglo. Para muchos científicos sociales (y no yerran), la Lima contemporánea es el resultado de ese nuevo mestizaje producido por el «desborde popular» que tan bien caracterizaran Matos Mar o Aníbal Quijano. No obstante, esta caracterización ha terminado por invisibilizar aquellas manifestaciones «andinas» propias de los limeños anteriores a dichas migraciones ${ }^{31}$.

La relevancia de esta localización del yaraví en el universo musical limeño y, junto con la zamacueca y la décima, de su incorporación en esa geografía sonora que representaba el paisaje sonoro de la ciudad venían a engrosar el repertorio musical que era considerado propio de la ciudad. El yaraví, en ese sentido, no constituía el único ejemplo de aquellos géneros cuyas particularidades melódicas y armónicas lo volvían originario del mundo andino y que, sin embargo, gozaba de una vitalidad plena en la capital peruana.

La mejor evidencia de dicha vitalidad se encuentra en la relación existente entre el vals y el yaraví como parte de su coexistencia en el paisaje sonoro de la ciudad. Ya en el año 2010, al editar el repertorio de Montes y Manrique, señalamos junto con Borras - lo que en ese momento parecían ser unos ejemplos aisladosla presencia de algunos yaravíes en el repertorio valsístico de los primeros años del siglo XX. Montes y Manrique habían incluido entre su repertorio una canción (triste) titulada La Carmela cuyo texto y algunas frases de la melodía habían pasado a convertirse, con variantes, en un vals de la Guardia Vieja atribuido

30 Aunque bastante anteriores, son interesantes las comparaciones elaboradas por Del Campo en el Mercurio Peruano entre el yaraví y el «zango» (una forma musical asociada a la población afro que a decir de este autor constituían «sonetes de las esquinas»). Del Campo dirá que ese «sonetillo que llaman zango está lleno de las mismas transiciones que le yaraví» (p. 114).

31 El caso más interesante de esto es el de la «lomera», una especie de huayno cuya única grabación — hasta que en el año 2013 la municipalidad de Lima recogiera dos piezas de este género entre dos habitantes de las zonas de lomas costeras que circundan Lima- pertenecía al conjunto de Alejandro Sáez y los hermanos Áscuez, tres afrodescendientes del distrito del Rímac que llevaron un ejemplo de dicha lomera a los surcos de los discos de la RCA Victor en el año de 1928. 
al compositor Pedro Arzola con el nombre de $R_{e b e c a^{32}}$. Algo similar sucedía con fragmentos de otro vals del mismo nombre (Rebeca) atribuido a Miguel Almenerio, sobre el que ya Zanutelli (1999) había llamado la atención en cuanto a sus fuentes literarias. Dicho autor lo consignaba como un poema titulado Yaraví, de Guillermo Bazo, incluido en un códice manuscrito de la Biblioteca Nacional del Perú: esos mismos fragmentos a los que se refería Zanutelli formaron parte del yaraví grabado por Montes y Manrique con el nombre de El pajarillo ${ }^{33}$.

Algo parecido puede afirmarse del vals La despedida de Abarca, grabado también por Montes y Manrique con el título de Abarca, pues dicho vals, además de estar construido estróficamente sobre la base de un conjunto de décimas atribuidas a Mariano Melgar, fue antes un yaraví y bajo esa forma convivió con su versión en vals al menos hasta la década de 1940, en que aún se le halla, sindicado como yaraví, dentro del cancionero El trovador ${ }^{34}$. Hasta aquí baste para apreciar no solo que el yaraví fue por un tiempo un género bastante productivo entre los limeños, sino sobre todo para comprender cómo, más tarde, frente a su paulatina desaparición como parte del universo musical de la capital peruana, muchos de sus textos, pero también ciertas características musicales, fueron a asentarse en los valses que comenzaron a componerse y a cantarse en los primeros años del siglo XX.

Como hemos apreciado hasta aquí, muchos ejemplos de los años iniciales del vals popular limeño revelan una filiación con el yaraví. Es curioso, por ejemplo, que pese al intento de César Santa Cruz por demostrar el parentesco del vals de la Guardia Vieja con los géneros de Europa central como el vals o la mazurca o, por otro lado, con la jota española, centrado sobre todo en las particularidades rítmicas de algunos ejemplos musicales, este autor no haya llamado la atención sobre un elemento que nos parece destacable en la mayor parte de los valses de este período que tiene que ver más con la progresión armónica de tónica-dominantetercer grado-dominante de tercer grado que es la que sigue el yaraví, de manera más o menos general, y otros géneros del área andina.

32 Otras fuentes identifican esta canción como un yaraví; por ejemplo, Cárdenas (1946).

33 Vale la pena señalar que de ese mismo vals aparece un fragmento en la pieza alusiva al carnaval de Montes y Manrique. Asimismo, esos mismos fragmentos incorporados al yaraví El pajarillo fueron grabados también por Gardel como parte del «estilo» (ese es nombre del género) La palomita; en el Perú además, se encuentran también esos versos dentro de otro yaraví titulado Trigueña.

34 El trovador $\mathrm{N}^{\mathrm{o}}$ 6, edición mensual s/f (p. 31). 
No es que no existan variantes a ese esquema dentro de esa forma del vals (como las había también dentro del yaraví); sin embargo, pese a las variantes, existe una constancia en dicho esquema, sobre todo si atendemos a la frase inicial que ejecuta la voz. Aunque esto no nos permita aseverar de manera categórica la consanguineidad entre los dos géneros, si sumamos a ellos (a este estilo del vals que suele comenzar en tonalidad menor) aquellos ejemplos que directamente provienen de yaravíes o tristes (como los valses Rebeca, Si dos con el alma o La despedida de Abarca), esto nos permitiría, al menos, pensar en una relación procedente de ese paisaje sonoro que los géneros tradicionales habían bosquejado entre los sectores populares.

Las evidencias más precisas sobre los elementos melódicos, rítmicos y armónicos de aquellos valses de la Guardia Vieja emparentados con otros géneros las encontramos en las grabaciones que la Columbia y la Victor Talking Machine realizaron a músicos limeños entre 1911 y $1930^{35}$. Aunque muchos de esos valses delaten aún numerosas huellas del vals de salón, otros muchos revelan una relación estrecha con géneros como el yaraví u otras formas musicales como las reseñadas por Santa Cruz en su trabajo sobre el vals, o aun con géneros en apariencia más lejanos musicalmente, como la marinera.

Todos estos elementos aparentemente menos perceptibles que se muestran como huellas de la convivencia en el universo sonoro popular de géneros muy diversos son los que permiten establecer una suerte de filiación entre algunos de estos valses y los géneros tradicionales. Esto bien pueden leerse en la clave ofrecida por Ángel Quintero con respecto a lo que él denomina «el tambor camuflado». Para Quintero, el proceso de modernización y adecentamiento de la música tropical - sobre todo la portorriqueña, que es la que él analiza - requirió, por un lado, el proceso de adopción de nuevos géneros y la conformación de nuevos ensambles; sin embargo, en muchas de las interpretaciones de estas nuevas agrupaciones dentro de los nuevos códigos estilísticos se mantuvieron elementos armónicos, pero sobre todo rítmicos — aunque de manera oculta — que delataban su procedencia afro. En muchos casos, esta tarea le fue confiada al «cuatro» en la

35 Como parte de esta interacción entre los géneros, vale la pena destacar, en cuanto a la instrumentación, la presencia del cajón en dos valses grabados por Cobián y Díaz en 1913, aunque dicha presencia se encuentre circunscrita a marcar los tiempos del vals por debajo del sonido de la guitarra. El cajón, como recuerda Santa Cruz, solía pensarse que estaba confinado solo a la interpretación de las marineras, resbalosas y de los tonderos. Sin embargo, en las grabaciones peruanas de la Victor Talking Machine se le puede hallar en otros géneros, como el vals o el huayno. 
música caribeña (Quintero, 1999); en el caso del vals un comportamiento similar parece haber sido adquirido por la guitarra en la intensidad de la marcación de los tiempos del vals o en algunas resoluciones de las introducciones instrumentales a las partes cantadas que se relacionaban con género de origen afrodescendiente. Sin embargo, no solo se camuflaron ritmos; al contrario, en el ropaje rítmico de la modernidad —el del vals - se camuflaron también ciclos armónicos que delatan sonoridades andinas.

\section{REFLEXIONES FINALES}

Aunque puedan parecer excepcionales o raros los ejemplos presentados en este artículo, allí se encuentran en las fuentes con las que buena parte de la academia peruana se ha topado en su trabajo de investigación durante el siglo XX. No son, además, las únicas fuentes. Si añadiésemos el retrato fotográfico, podríamos ampliar rápidamente nuestras sospechas, pues en estos años de trabajo con la prensa y con todo tipo de archivos me he hallado con imágenes que contravienen también ese «orden de las cosas» en el que tan cómodamente hemos vivido tanto tiempo: vendedoras de turrón de doña pepa indígenas —o es lo que parece sugerir su vestimenta - en la década 1910, tocadores de pinkullos en Amancaes y en el cerro San Cristóbal en esos mismos años, en fin, numerosas imágenes que deberían, al menos, obligarnos a repensar lo que por tantos años hemos creído y hemos afirmado. ¿Esto quiere decir que Lima en los primeros años del siglo XX era una panacea de la cultura andina? No lo sé, quizás ni yo lo creo. No obstante, existen, a nuestro juicio, suficientes evidencias de la existencia de un conjunto de manifestaciones consideradas hoy andinas con las que toda la ciudad convivía y a las que, en parte, se había ya habituado. Ellas no provienen de las grandes migraciones que remodelaron nuestra ciudad desde mediados del siglo XX y, lamentablemente, han sido invisibilizadas primero, quizás, por quienes recrearon un nuevo imaginario de lo limeño, pero fueron sancionadas, después, por nuestra academia en más de medio siglo de docencia y de investigación. Creo, por ello, que todo intento por reconstruir un conjunto de lazos entre limeños y peruanos, que por tanto tiempo se han pensado distinto, pasa también por intentar analizar cuánto tuvieron y cuánto tienen en común. 


\section{REFERENCIAS BIBLIOGRÁFICAS}

Aguirre, Carlos (1993). Agentes de su propia libertad: los esclavos de Lima y la desintegración de la esclavitud, 1821-1854. Lima: PUCP.

Anderson, Benedict (2007). Comunidades imaginadas. Reflexiones sobre el origen y la difusión del nacionalismo. Ciudad de México: Fondo de Cultura Económica.

Andrade, Luis (2009). En Actas del II Congreso Internacional de Lexicología y Lexicografía en homenaje a Diego de Villegas y Quevedo Saavedra (pp. 71-97). Academia Peruana de la Lengua

Arguedas, José María (1989). Indios, mestizos y señores. Tercera edición. Lima: Horizonte.

Arona de, Juan (1938). Diccionario de peruanismos. París: Desclée de Brouwer.

Arrelucea, Maribel y Cosamalón, Jesús (2015). La presencia afrodescendiente en el Perú, siglos XVI-XX. Lima: Ministerio de Cultura.

Arróspide de la Flor, César (1971). La música de teatro en el Virreynato de Lima. Revista Musical Chilena, 25(115-1) [Online] (consulta 18 de abril de 2012) http://www. revistas.uchile.cl/index.php/RMCH/article/viewFile/1608/1489

Áscuez, Augusto (1983). Los carnavales que yo jugué. VSD, Suplemento cultural de La República 11.2.1983, p. 15.

Belaunde, Víctor Andrés (1933). El debate constitucional. Discursos en la Asamblea 1931-1932. Lima: Imprenta La Tradición.

Borras, Gérard y Fred Rohner (2010). Montes y Manrique. 100 años de música peruana. Lima: IFEA / IDE-PUCP.

Borras, Gérard y Fred Rohner (2013). La música popular peruana. Lima-Arequipa (1913-1917). Lima: IFEA / IDE-PUCP.

Burga, Manuel y Alberto Flores Galindo (1984). Apogeo y crisis de la República Aristocrática. Lima: Rikchay Perú.

Capello, Joaquín y Richard Morse (1973). Lima en 1900. Estudio crítico y antología. Lima: IEP.

Cárdenas, Fortunato (1946). La huerta de Tarma. Tarma: s.e.

Carpio Muñoz, Guillermo (1976). El yaraví arequipeño. Un estudio histórico-social y un cancionero. Arequipa: s.e.

Carrera, Eudocio (1954). La Lima criolla de 1900 (corregida y aumentada). Lima: Sanmarti y Cia.

Cornejo Polar, Antonio (1989). La formación de la tradición literaria en el Perú. Lima: CEP. 
Cosamalón, Jesús (1999). Indios detrás de la muralla: indígenas y convivencia interracial en San Ana (Lima, 1795-1820). Lima: Fondo Editorial de la Pontificia Universidad Católica del Perú.

Del Águila, Alicia (1997). Callejones y mansiones: espacios de opinión pública y redes sociales y políticas en la Lima del 900. Lima: Fondo Editorial de la Pontifica Universidad Católica del Perú.

Denegri, Francesca (2004). El abanico y la cigarrera. La primera generación de mujeres ilustradas en el Perú. Lima: IEP/Centro de la Mujer Peruana Flora Tristán.

Estenssoro, Juan Carlos (1989). Música y sociedad coloniales, Lima 1680-1830. Lima: Colmillo Blanco.

Estenssoro, Juan Carlos (1996). La plebe ilustrada: el pueblo en las fronteras de la razón. En Charles Walker (comp.), Entre la retórica y la insurgencia. Las ideas y los movimientos sociales en los Andes, siglo XVIII (pp. 33-66). Cusco: Centro de Estudios Regionales Andinos Bartolomé de las Casas.

Flores Galindo, Alberto (1984). Aristocracia y plebe: Lima, 1760-1830 (Estructura de clases y sociedad colonial). Lima: Mosca Azul Editores.

Flores Galindo, Alberto (2005). Buscando un inca: identidad y utopía en los Andes. Lima: SUR Casa de Estudios del Socialismo.

Fuenzalida, Fernando (2009). Poder, raza y etnia en el Perú contemporáneo. En Fernando Fuenzalida, La agonía del Estado-Nación. Poder raza y etnia en el Perú contemporáneo (pp. 141-204). Lima: Fondo Editorial del Congreso del Perú.

Gálvez, José (Proama) (1912). El carnaval. Variedades, 208, 24 de febrero.

Gómez Acuña, Luis (2007). Lo criollo en el Perú republicano. Breve aproximación a un término elusivo. Histórica, 31(2), 116-166. Lima: PUCP.

Gómez Acuña, Luis (2010). Música criolla. Cultural practices and National issues in modern Peru. The case of Lima. Nueva York: Stony Brook University.

González Prada, Manuel (1976 [1888]). Discurso en el Politeama. En Pájinas libres. Horas de lucha (pp. 43-48). Caracas: Biblioteca Ayacucho. Disponible en http://www.biblioteca.org.ar/libros/211590.pdf

Gorriti, Juana Manuela (1892). Veladas literarias de Lima. Buenos Aires: Imprenta Europea.

Lloréns, José Antonio (1983). Música popular en Lima: andinos y criollos. Lima: IEP / Instituto Indigenista Interamericano.

Lloréns, José Antonio y Rodrigo Chocano (2009). Celajes, florestas y secretos: una historia del vals popular limeño. Lima: Instituto Nacional de Cultura. 
Mariátegui, José Carlos (1957). 7 Ensayos de interpretación de la realidad peruana. Lima: Biblioteca Amauta.

Marquina Ríos, Hugo (1957). Cincuenta casas de vecindad en la avenida Francisco Pizarro. En C. E. Paz Soldán, Lima y sus suburbios. Lima: UNMSM.

Méndez, Cecilia (2000). Incas sí, indios no. Apuntes para el estudio del nacionalismo criollo en el Perú. Documentos de trabajo 56. Lima: IEP.

Méndez, Cecilia (2011). De indio a serrano. Nociones de raza y geografía en el Perú (siglos XVIII-XXI). Histórica, XXXV(1), 53-102.

Mendoza, Zoila (2006). Crear y sentir lo nuestro. Folklore, identidad regional y nacional en el Cuzco, siglo XX. Lima: PUCP.

Muñoz, Fanni (2001). Diversiones públicas en Lima: 1890-1920. La experiencia de la modernidad. Lima: Red para el Desarrollo de las Ciencias Sociales en el Perú.

Pagaza, Consuelo (1960). El Yaraví. Folklore Americano, VIII-IX(8). Lima.

Palma, Ricardo (1953). Tradiciones peruanas completas. Madrid: Aguilar.

Panfichi, Aldo (1998). Urbanización temprana de Lima. 1535-1900. En Aldo Panfichi y Felipe Portocarrero (eds.), Mundos interiores. Lima 1850-1950. Lima: Universidad del Pacífico.

Paz Soldán, Carlos Enrique (1957). Lima y sus suburbios. Lima: Universidad Nacional de San Marcos de Lima / Biblioteca de Cultura Sanitaria.

Prince, Carlos (2011 [1890]). Lima Antigua. Tipos de antaño con numerosas viñetas. Lima: Casa del Libro Viejo.

Quintero Rivera, Ángel G. (1999). Salsa, sabor y control: sociología de la música tropical. Ciudad de México: Siglo Veintiuno.

Rebagliati, Claudio (s/f). Álbum sudamericano. Colección de bailes y cantos populares corregidos y arreglados para piano op. 16. Milán: Stabilimento de Edoardo Sonzogno.

Riva Agüero, José de la (1905). Carácter de la literatura del Perú independiente. Lima: Librería Francesa Científica Galland.

Rohner, Fred (2006). Notas para el estudio y la edición de la lírica popular limeña. Lexis, 30(2), 291-308.

Rohner, Fred (2015). Una aproximación a la generación de Felipe Pinglo: la Guardia Vieja y el rol de las industrias culturales en la configuración del canon musical criollo. En R. Romero (ed.), Música popular y sociedad en el Perú contemporáneo (pp. 69-99). Lima: IDE-PUCP. 
Rojas, Rolando (2005). Tiempos de carnaval. El ascenso de lo popular a la cultura nacional (Lima 1822-1922). Lima: IFEA / IEP.

Rojas, Rolando (2014). A favor de la rehistorización de las ciencias sociales. Argumentos, 8(5), noviembre. Lima: IEP.

Romero, Raúl R. (2012). Hacia una antropología de la música. La etnomusicología en el Perú. En Carlos Iván Degregori, No hay país más diverso. Compendio de antropología peruana II (pp. 289-329). Lima: IEP.

Salazar Mejía, Luis (2010). Artículo Rambo en Lima. Las grabaciones de la Víctor en setiembre de 1913. Publicado en el blog Músicas del Perú. Setiembre. http:// folcloremusicalperuano.blogspot.com/2010_09_01_archive.html

Salazar Mejía, Luis (2014). Declaración del 23 de febrero de 2014 en un ciclo de conferencias organizado por Rafael Santa Cruz en el Centro Cultural de España (Lima) titulada Hablando de música: Las primeras grabaciones peruanas. CCE, 23 de febrero de 2014.

Santa Cruz, César (1989). El waltz y el valse criollo. Lima: Concytec.

Schafer, Murray (1977). The tuning of the world (soundscape). Ann Arbor, MI: University of Michigan.

Sociedad Amantes del País (1791-1794). Mercurio Peruano. Edición faccimilar. Lima: BNP, 1960-1965.

Stein, Steve (1986). Lima obrera: 1900-1930, tomo I. Lima: El Virrey.

Stokes, Susan (1987). Etnicidad y clase social: los afroperuanos de Lima, 1900-1930. En Steve Stein (comp.), Lima obrera. 1900-1930, tomo II. Lima: El Virrey.

Tompkins, William D. (2011). Las tradiciones musicales de los negros de la costa del Perú. Traducción de Juan Luis Dammert y Raquel Paraíso. Lima: Centro de Música y Danza de la Pontificia Universidad Católica del Perú, Centro Universitario de Folklore de la Universidad Nacional Mayor de San Marcos.

Tristán, Flora (2003). Peregrinaciones de una paria. Lima: Centro de la Mujer Peruana Flora Tristán / Fondo Editorial UNMSM

Zanutelli Rosas, Manuel (1999). Canción criolla, memoria de lo nuestro. Lima: Diario El Sol. 